\title{
Prevalence of Methicillin Resistance and Panton-Valentine Leukocidin Genes in Staphylococci Isolated from Pirlak Sheep with Subclinical Mastitis in Turkey
}

\author{
Esra ŞEKER ${ }^{1, *}$, Erhan ÖZENÇ², Duygu BAKİ ACAR², Müesser YÍLMAZ³ \\ ${ }^{1}$ Department of Microbiology, Faculty of Veterinary Medicine, Afyon Kocatepe University, Afyonkarabisar, Turkey \\ ${ }^{2}$ Department of Obstetrics and Gynaecology, Faculty of Veterinary Medicine, Afyon Kocatepe University, Afyonkarahisar, Turkey \\ 'Institute of Health Science, Afyon Kocatepe University, Afyonkarahisar, Turkey
}

\begin{abstract}
This study aimed to investigate the presence of mec $A$ and $p v l$ genes in 47 Staphylococci previously isolated from 464 half-udder milk samples belong to 235 Pirlak sheep screening for subclinical mastitis. The species from Pirlak sheep used in the present study included: 13 S. aureus, 13 S. epidermidis, six S. xylosus, five S. chromogenes, three $S$. simulans, three S. byicus, two S. warneri, one S. lentus and one S. saprophyticus. A total of 10 strains (21.3\%) were determined to harbour mec $A$ gene, of these, two $(4.2 \%)$ also contained $p v l$ gene. The strains carrying $m e c A$ gene were found to be $S$. aureus (3/13), S. xylosus (3/6), S. epidermidis (2/13), S. lentus (1/1) and S. byicus (1/3). The presence of $p v l$ gene was determined in a total of eight strains $(17.0 \%)$, six $(12.8 \%)$ of these were alone. Of $p v l$ positive strains, three, three, one, and one were $S$. aureus, S. xylosus, S. simulans and S. byicus, respectively. To our knowledge, this is the first study showing the presence of mec $A$ and $p v l$ genes in the Staphylococci isolated from Pirlak sheep with subclinical mastitis in Turkey.
\end{abstract}

Keywords: Mastitis, Methicillin Resistance, Panton-Valentine Leukocidin, Sheep, Staphylococci

\section{Türkiye'de Subklinik Mastitisli Pırlak Koyunlardan İzole Edilen Stafilokoklarda Metisilin Direnç ve Panton-Valentine Lökosidin Genlerinin Prevalansı}

\section{ÖZ}

Bu çalışmada, subklinik mastitis yönünden taranan 235 Pırlak koyuna ait 464 meme lobu süt örneğinden daha önce izole edilen 47 Stafilokok türünde mec $A$ ve $p v l$ genlerinin varlığının araştırılması amaçlandı. Çalışmada, Pırlak koyunlardan izole edilen 13 S. aureus, 13 S. epidermidis, alt1 S. xylosus, beş S. chromogenes, üç S. simulans, üç S. byicus, iki S. warneri, bir $S$. lentus ve bir $S$. saprophyticus suşu kullanıldı. Toplam 10 suşun $(\% 21,3)$ mec $A$ geni taşıdığ1, bunlardan ikisinin $(\% 4,2)$ ayrıca $p v l$ genine de sahip olduğu belirlendi. mec $A$ geni taşıyan suşlar S. aureus (3/13), S. xylosus (3/6), S. epidermidis (2/13), S. lentus (1/1) ve S. hyicus (1/3) olarak bulundu. Toplam sekiz suşta $(\% 17,0)$ pvl geni belirlenirken, bunlardan altısının $(\% 12,8)$ bu geni tek başına taşıdığı tespit edildi. pvl pozitif suşların üçü $S$. aureus, üçü S. xylosus, biri S. simulans ve biri S. byicus olarak belirlendi. Bilgimize göre, bu çalışma Türkiye'de subklinik mastitisli Pırlak koyunlardan izole edilen Stafilokoklarda mecA ve pvl genlerinin varlığını gösteren ilk çalışmadır.

Anahtar Kelimeler: Koyun, Mastitis, Metisilin Direnci, Panton-Valentine Lökosidin, Stafilokok

To cite this article: Seker E. Özenc E. Baki Acar D. Yilmaz. M. Prevalence of Methicillin Resistance and Panton-Valentine Leukocidin Genes in Staphylococci Isolated from Pirlak. Sheep with Subclinical Mastitis in Turkey. Kocatepe Vet J. (2019), 12(4):424-429. 


\section{INTRODUCTION}

The importance of methicillin resistant Staphylococci (MRS), especially methicillin resistant Staphylococcus aureus (MRSA), has been emphasized in terms of public and animal health because these agents have been accepted to be humanosis and/or zoonosis pathogens (Pantosti 2012). Methicillin resistance has become an increasing urgent problem in veterinary medicine after the first report of MRSA in dairy cows with mastitis (Cuny et al. 2010, Caruso et al. 2016, Aires-de-Sousa 2017). This resistance results from the production of an alternative penicillin-binding protein (PBP2a or PBP2') encoded by the mecA gene (Pinho et al. 2001). Although sufficient data on the presence of mec $A$ gene in Staphylococci, particularly $S$. aureus strains, isolated from bovine mastitic milk samples have been found (Moon et al. 2007, Türkyllmaz et al. 2010, Gezgen and Seker 2016), the investigations related to the prevalence of this gene in Staphylococci isolated from sheep are limited (Vyletělová et al. 2011, Ünal and Çinar 2012, Ünal et al. 2012).

Panton-Valentine leukocidin (PVL) encoded by lukFPV and lukS-PV genes is a leukocytolytic toxin causing leukocyte destruction and tissue necrosis (Yoong and Torres 2013). Although epidemiologically the PVL toxin has been linked to communityacquired methicillin resistant $S$. aureus infections (CAMRSA) in the past (Lo and Wang 2011), nowadays, it has been shown that PVL may be found in both methicillin susceptible $S$. aureus (MSSA) and MRSA strains (Sharma-Kuinkel et al. 2012). The role of PVL in human Staphylococcal infections is not clear and remains an issue of contention (Sharma-Kuinkel et al. 2012). Similarly, its pathogenic role in the pathogenesis of mastitis is still controversial (Ikawaty et al. 2010, Gezgen and Seker 2016).

The Pirlak breed obtained by crossing the Daglic with the Kivircik has a feature between these two breed in terms of basic phenotypic and production performance characteristics. This mid-sized coarse wool sheep also produces meat and milk and is raised in some provinces of the Aegean, Marmara and Mediterranean regions in Turkey (Yilmaz et al. 2013). The researches on the etiology of mastitis in this particular breed are limited (Ozenc et al. 2011) and any data has not been also described on the presence of methicillin resistance and Panton-Valentine leukocidin genes in the Staphylococci isolated from Pirlak sheep. Therefore, we aimed to investigate the $\operatorname{mec} A$ and $p v l$ genes in Staphylococci previously isolated from Pirlak sheep with subclinical mastitis in Afyonkarahisar province of Turkey..

\footnotetext{
MATERIALS and METHODS

\section{Bacterial strains}

A total of 47 Staphylococci isolates used in this study were previously isolated from 464 half-udder milk samples belong to 235 Pirlak sheep screening for
}

subclinical mastitis in Afyonkarahisar, Turkey. All isolates were confirmed using Crystal ${ }^{\mathrm{TM}}$ Identification Systems Gram-Positive ID kit (Becton, Dickinson and Company, NJ, USA). The species from Pirlak sheep used in the present study included: $13 \mathrm{~S}$. aureus, 13 Staphylococcus epidermidis, six Staphylococcus xylosus, five Staphylococcus chromogenes, three Staphylococcus simulans, three Staphylococcus byicus, two Staphylococcus warneri, one Staphylococcus lentus and one Staphylococcus saprophyticus.

\section{Detection of 16S rDNA, mecA and pvl genes by PCR}

In this study, MRSA ATCC® 33591 and PVL S. aureus ATCC $\mathbb{R} 49775$ strains were used as positive control strains and MSSA ATCC® 25923 was used as negative control strain (Oxoid Microbiology Products, Hampshire, UK). DNAs were extracted from control and all test strains using boiling method. The fresh colonies growing on Trypticase Soy Agar (Oxoid Microbiology Products, Hampshire, UK) were suspended in eppendorf tubes containing 500 $\mu \mathrm{L}$ of sterile deionized water and the tubes were held in a $100^{\circ} \mathrm{C}$ of water bath for $10 \mathrm{~min}$. After this process, the suspension was centifugated at 9,167 $\mathrm{g}$ for $5 \mathrm{~min}$ and the supernatant was used for PCR assay (Gezgen and Seker 2016).

Duplex PCR was used for the detection of $16 \mathrm{~S}$ rDNA and mec $A$ genes, while singleplex PCR was performed for $p v l$ gene. A total of $25 \mu \mathrm{L}$ PCR mixture included $2.5 \mu \mathrm{L}$ 10X PCR buffer, $25 \mathrm{mM} \mathrm{MgCl} 2,10 \mathrm{mM}$ dNTP mix, $20 \mu \mathrm{M}$ each primers, $1 \mathrm{U}$ of Taq DNA polymerase, $5 \mu \mathrm{L}$ of template DNA and deionized water. The oligonucleotide primers and PCR amplification conditions of $16 \mathrm{~S} \mathrm{rDNA}$, mec $A$ and $p v l$ genes were shown in Table 1 and Table 2, respectively. All products were analyzed by 1.5\% agarose gel electrophoresis and visualized using ethidium bromide under U.V. light.

\section{RESULTS}

All of 47 Staphylococcus strains obtained from halfudder milk samples of Pirlak sheep showed 16S rDNA specific bands. A total of $10(21.3 \%)$ strains were determined to harbour mec $A$ gene, of these, two $(4.2 \%)$ also contained $p v l$ gene. The strains carrying mec $A$ gene were found to be $S$. aureus $(\mathrm{n}=3), S$. xylosus $(\mathrm{n}=3)$, S. epidermidis $(\mathrm{n}=2)$, S. lentus $(\mathrm{n}=1)$ and $S$. hyicus $(\mathrm{n}=1)$ (Figure 1). The presence of $p v l$ gene was determined in a total of eight strains $(17.0 \%)$. Of $p v l$ positive strains, three, three, one, and one were $\mathrm{S}$. aureus, $S$. xylosus, $S$. simulans and $S$. byicus, respectively (Figure 2). The distribution of mec $A$ and $p v /$ genes was shown in Table 3. 
Tablo 1. Çalışmada kullanılan oligonükleotid primerleri

Table 1. Oligonucleotide primers used in this study

\begin{tabular}{|c|c|c|c|}
\hline Gene & Sequence $\left(5^{\prime} \rightarrow 3^{\prime}\right)$ & \multicolumn{2}{|c|}{ Reference } \\
\hline \multirow[t]{2}{*}{$16 \mathrm{~S} \mathrm{rDNA}$} & CAGCTCGTGTCGTGAGATGT & 420 & Strommenger et al. 2003 \\
\hline & AATCATTTGTCCCACCTTCG & & \\
\hline \multirow[t]{2}{*}{$\operatorname{mec} A$} & CCTAGTAAAGCTCC GAA & 314 & Choi et al. 2003 \\
\hline & CTAGTCCATTCGGTCCA & & \\
\hline \multirow[t]{2}{*}{$p v l$} & ATCATTAGGTAAAATGTCTGGACATGATCCA & 433 & Lina et al. 1999 \\
\hline & GCATCAASTGTATTGGATAGCAAAAGC & & \\
\hline
\end{tabular}

Tablo 2. 16S rDNA, mec $A$ ve $p v l$ genleri için PZR amplifikasyon koşulları.

Table 2. PCR amplification conditions of $16 \mathrm{~S}$ rDNA, mec $A$ and $p v l$ genes (Gezgen and Seker 2016)

\begin{tabular}{|c|c|c|c|c|c|}
\hline \multirow[t]{3}{*}{ Step } & \multirow[t]{3}{*}{ Cycle } & \multicolumn{2}{|c|}{ Temperature } & \multicolumn{2}{|c|}{ Time } \\
\hline & & mec $A$ and $16 \mathrm{~S}$ & $p v l$ & $m e c A$ and $16 \mathrm{~S}$ & $p v l$ \\
\hline & & rDNA & & rDNA & \\
\hline Initial denaturation & 1 & $95^{\circ} \mathrm{C}$ & $95^{\circ} \mathrm{C}$ & $5 \mathrm{~min}$ & $5 \mathrm{~min}$ \\
\hline Denaturation & 30 & $95^{\circ} \mathrm{C}$ & $94^{\circ} \mathrm{C}$ & $2 \min$ & $30 \mathrm{sec}$ \\
\hline Annealing & 30 & $54^{\circ} \mathrm{C}$ & $62^{\circ} \mathrm{C}$ & $1 \mathrm{~min}$ & $30 \mathrm{sec}$ \\
\hline Extension & 30 & $72^{\circ} \mathrm{C}$ & $72^{\circ} \mathrm{C}$ & $1 \mathrm{~min}$ & $1 \mathrm{~min}$ \\
\hline Final extension & 1 & $72^{\circ} \mathrm{C}$ & $72^{\circ} \mathrm{C}$ & $7 \mathrm{~min}$ & $5 \mathrm{~min}$ \\
\hline
\end{tabular}

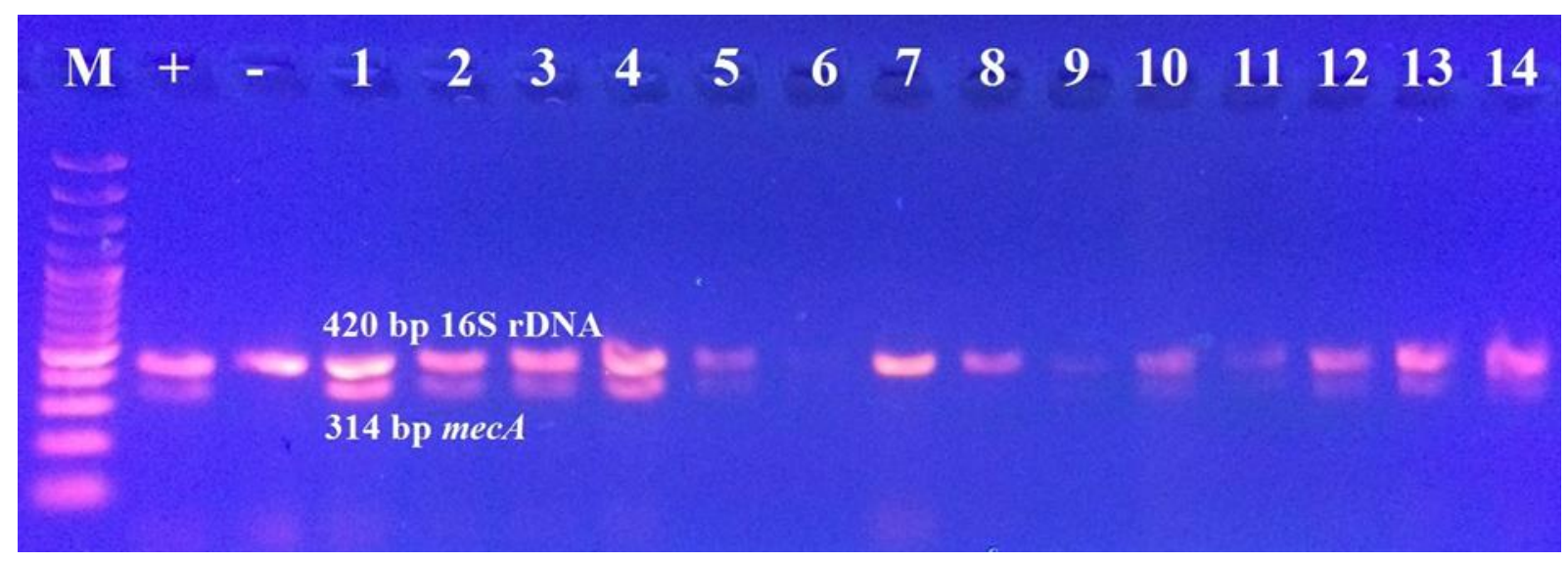

Şekil 1. 16S rDNA ve mecA genlerinin dubleks PZR ile belirlenmesi. M: 100 bp DNA ladder; +: pozitif kontrol (MRSA ATCC® 33591); -: negatif kontrol (MSSA ATCC® 25923); sütun 1-3: mecA geni pozitif $S$. aureus suşlar1; sütun 4,5,10: mecA geni pozitif $S$. xylosus suşlar1; sütun 6: 16SrDNA negatif kontrol (steril distile su); sütun 11,12: mec $A$ geni pozitif $S$. epidermidis suşlar1; sütun 13: mec $A$ geni pozitif $S$. lentus suşu; sütun 14: mec $A$ geni pozitif $S$. byicus suşu

Figure 1. Detection of $16 \mathrm{~S}$ rDNA and mec $A$ genes by dublex PCR. M: 100 bp DNA ladder; +: positive control (MRSA ATCC® 33591); -: negative control (MSSA ATCC® 25923); lane 1-3: mecA gene positive $S$. aureus strains; lane 4,5,10: mec $A$ gene positive $S$. xylosus strains; lane 6: $16 \mathrm{SrDNA}$ negative control (sterile distilled water); lane 11,12: mec $A$ gene positive $S$. epidermidis strains; lane 13: mec $A$ gene positive $S$. lentus strain; lane 14: mec $A$ gene positive $S$. byicus strain. 


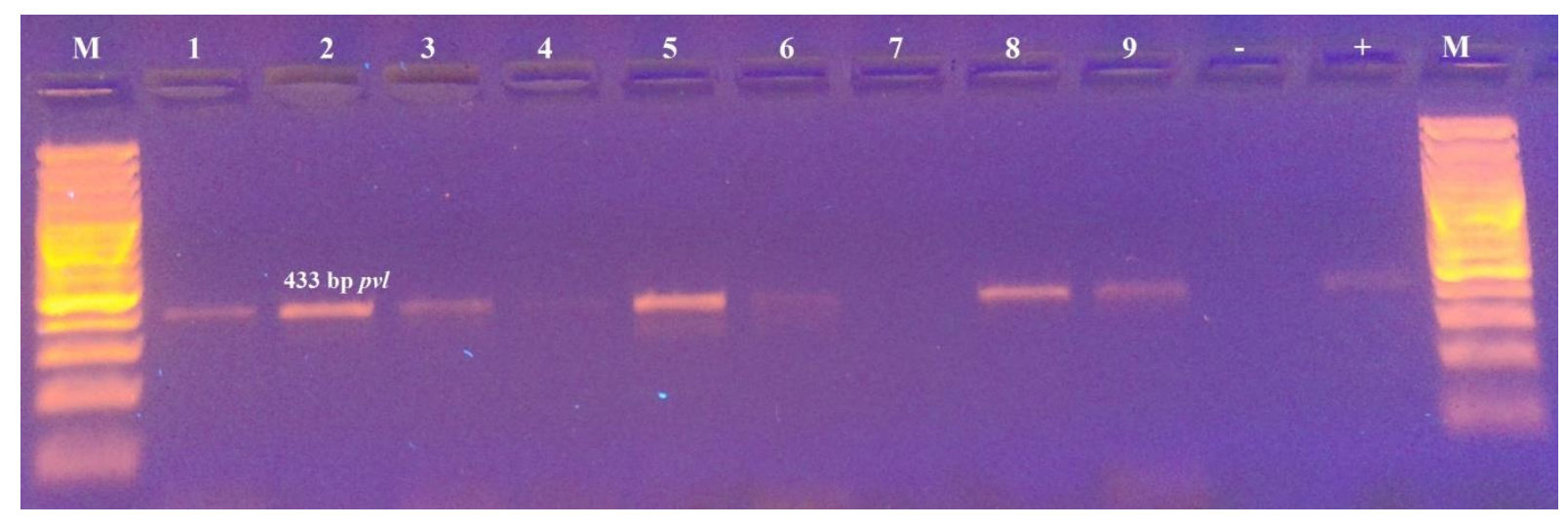

Şekil 2. PZR ile pvl geninin belirlenmesi. M: 100 bp DNA ladder; sütun 1-3: pvl geni pozitif S. aureus suşlar1; sütun 4-6: $p v l$ geni pozitif $S$. xylosus suşları; sütun 7: $p v l$ geni negatif suş; sütun 8: pvl geni pozitif $S$. simulans suşu; sütun 9: pvl geni pozitif $S$. hyicus suşu; -: negatif kontrol (steril distile su); +: pozitif kontrol (PVL S. aureus ATCC® 49775).

Figure 2. Detection of $p v l$ gene by PCR. M: 100 bp DNA ladder; lane 1-3: pvl gene positive $S$. aureus strians; lane 4-6: $p v l$ gene positive $S$. xylosus strains; lane 7: $p v l$ gene negative strain; lane 8: $p v l$ gene positive S. simulans strain; lane 9: pvl gene positive $S$. byicus strain; -: negative control (sterile distilled water); +: positive control (PVL S. aureus ATCC® 49775).

Tablo 3. Subklinik mastitisli Prrlak koyunlardan izole edilen Stafilokoklarda PZR ile belirlenen mec $A$ ve pvl genlerinin dağıllımı.

Table 3. Distribution of mec $A$ and $p v l$ genes detected by PCR in Staphylococci isolated from Pirlak sheep with subclinical mastitis.

\begin{tabular}{lcc}
\hline Species (no of tested strain) & Genes & No of isolates \\
\hline S. aureus $(\mathrm{n}=13)$ & mec $A$ & 2 \\
& pvl & 2 \\
& $\operatorname{mec} A$, pvl & 1 \\
S. epidermidis $(\mathrm{n}=13)$ & $\operatorname{mec} A$ & 2 \\
S. xylosus $(\mathrm{n}=6)$ & $\operatorname{mec} A$ & 2 \\
& pvl & 2 \\
S. chromogenes $(\mathrm{n}=1)$ & mec $A$, pvl & 1 \\
S. simulans $(\mathrm{n}=3)$ & - & - \\
S. hyicus $(\mathrm{n}=3)$ & pvl & 1 \\
& mec $A$ & 1 \\
S. warneri $(\mathrm{n}=2)$ & pvl & 1 \\
S. lentus $(\mathrm{n}=1)$ & - & - \\
S. saprophyticus $(\mathrm{n}=1)$ & mec $A$ & 1 \\
\hline
\end{tabular}

\section{DISCUSSION}

The present study investigated the presence of mec $A$ and $p v l$ genes in Staphylococci previously isolated from Pirlak sheep with subclinical mastitis.

Staphylococci are the most common etiologic agents isolated from subclinical mastitis cases in sheep (Ozenc et al. 2011, Gelasakis et al. 2015, Queiroga 2017). In recent years, methicillin resistance mediated by the mec $A$ gene has been increasingly reported in Coagulase Negative Staphylococci (CNS) as well as in $S$. aureus isolated from bovine mastitic milk samples (Vyletělová et al. 2011, Ünal and Çinar 2012, Gelasakis et al. 2015). However, the reports and data related to the prevalence of this gene in Staphylococci isolated from sheep with subclinical mastitis are limited (Vyletělová et al. 2011, França et al. 2012, Ünal et al. 2012, Martins et al. 2015). Vyletělová et al. 
(2011) reported that the mec $A$ gene was obtained in none of $S$. aureus and $S$. lentus strains isolated from sheep with subclinical mastitis. In another study, it was emphasized that none of 37 Staphylococci strains isolated from ovine subclinical mastitic milk samples harboured the mec $A$ gene (França et al. 2012). Martins et al. (2015) reported that none of 18 S. aureus strains obtained from 473 subclinical mastitic milk samples were carried the mec $A$ gene. Similarly, Ünal et al. (2012) from Turkey emphasized that none of $21 S$. aureus strains isolated from ewes' milk harboured the mec $A$ gene. In another study from Turkey, it was reported that $\operatorname{mec} A$ positivity was found in three $(7.5 \%)$ of $40 \mathrm{CNS}$ strains isolated from ewes with subclinical mastitis. In the same study, two and one of mec $A$ positive strains were identified to be $S$. lentus and S. xylosus, respectively (Ünal and Çinar 2012). In our study, mec $A$ positivity was found in 10 of 47 (21.3\%) Staphylococci strains isolated from Pirlak sheep with subclinical mastitis. The strains carrying mec $A$ gene were determined to be $S$. aureus (3/13), $S$. xylosus (3/6), S. epidermidis (2/13), S. lentus (1/1) and $S$. byicus $(1 / 3)$. Compared the other investigations from different countries, the mec $A$ positivity obtained from our study may be associated with the intensive and prolonged use of nonspecific antibiotics for the treatment of mastitis in Turkey. However, the geographical variations may be effective on the difference of mec $A$ gene prevalence in the strains. These results also showed that CNS, like as S. aureus, isolated from Pirlak sheep may be potential reservoirs for mec $A$ genes and this may pose a public health risk in terms of dissemination of methicillin resistant strains. It was reported that $\operatorname{mec} A$ positive CNS strains may transfer the resistance gene to $S$. aureus and other Staphylococci (Huber et al. 2011).

PVL is one of the most important and extensively investigated proteins that belong to bicomponent synergohymenotropic toxins family (Yoong and Torres 2013). Although PVL is frequently reported as a common virulence factor in MRSA strains, especially CA-MRSA strains, this toxin gene has also been isolated from MSSA in recent years (Strommenger et al. 2003). It has been reported these bicomponent toxins are secreted by some strains of mastitis-causing $\mathrm{S}$. aureus, but data on the prevalence of leukotoxins among strains obtained from small ruminants with mastitis is limited. In Brazil, while Aires-de-Sousa et al. (2007) reported that none of the 16 Staphylococci isolates obtained from sheep harboured the $p v l$ gene, Martins et al. (2015) emphasized the exotoxin PVL was detected in only one $(5.5 \%)$ strain of 18 mec $A$ negative $S$. aureus strains obtained from sheep with subclinical mastitis. In a study from Turkey, it was reported that 14 (66.6\%) of the $21 \mathrm{~S}$. aureus isolates from mastitic milk samples of small ruminants had pvl gene while none of the isolates harboured mec $A$ gene (Ünal et al. 2012). In another study, Ünal and Çinar (2012) determined the pol gene in one $S$. simulans and one $S$. warneri strain among 40 ewe CNS isolates. In the same study, the researchers emphasized none of mec $A$ positive strains harboured the $p v l$ gene. According to results of our study, a total of eight $(17.0 \%)$ strains had the pvl gene, six of these were alone. The $p v l$ gene positive strains were determined to be $S$. aureus (3/13), $S$. xylosus (3/6), S. simulans (1/3) and S. byicus (1/3). (Table 3). These findings suggested that pol gene may also be common in CNS isolates and may also be present in mec $A$ negative strains. Rainard and Riollet (2006) reported that the neutrophil phagocytosis is a significant defense factor against bacteria causing mastitis on the mammary gland of ruminants. Although the role of PVL on mastitis is not clearly understood, the production of this leukotoxin may give more advantages to Staphylococci to resist host defense mechanisms and to settle in the mammary gland.

The present study revealed that CNS, like as S. aureus, isolated from Pirlak sheep could be potential reservoirs of mec $A$ and $p v l$ genes. This may pose a public health risk due to the horizontal transfer of these attributes of pathogenicity to commensals or pathogenic bacteria. In our study, it was also shown that the $p v l$ gene could also be found in mec $A$ negative strains as well as in $\operatorname{mec} A$ positive strains. Although the strains carrying both $p v l$ and mec $A$ genes are considered to be more pathogenic, it should not be ignored the other strains carrying these genes alone, especially CNS strains, may also be potential pathogens for human and animals.

\section{REFERENCES}

Aires-de-Sousa M. Methicillin-resistant Staphylococcus aureus among animals: current overview. Clin Microbiol Infect. 2017; 23: 373-380.

Aires-de-Sousa M, Parente CESR, Vieira-da-Motta O, Bonna ICF, Silva DA, de Lencastre $\mathbf{H}$. Characterization of Staphylococcus aureus isolates from buffalo, bovine, ovine, and caprine milk samples collected in Rio de Janeiro State, Brazil. Appl Environ Microbiol. 2007; 73: 3845-3849.

Caruso M, Latorre L, Santagada G, Fraccalvieri R, Miccolupo A, Sottili R, Palazzo L, Parisi A. Methicillin-resistant Staphylococcus aureus (MRSA) in sheep and goat bulk tank milk from Southern Italy. Small Rumin Res. 2016; 135: 26-31.

Choi SM, Kim SH, Kim HJ, Lee DG, Choi JH, Yoo JH, Kang JH, Shin WS, Kang MW. Multiplex PCR for detection of genes encoding aminoglycoside modifying enzymes and methicillin resistance among Staphylococcus species. J Korean Med Sci. 2003; 18: 631-636.

Cuny C, Friedrich A, Kozytska S, Layer F, Nübel U, Ohlsen K, Strommenger B, Walther B, Wieler L, Witte W. Emergence of methicillin-resistant Staphylococcus aureus (MRSA) in different animal species. Int J Med Microbiol. 2010; 300: 109-117.

França CA, Peixoto RM, Cavalcante MB, Melo NF, Oliveira CJB, Veschi JA, Mota RA, Costa MM. Antimicrobial resistance of Staphylococcus spp. from small ruminant mastitis in Brazil. Pesqui Vet Bras. 2012; 32: 747-753. 
Gelasakis AI, Mavrogianni VS, Petridis IG, Vasileiou NGC, Fthenakis GC. Mastitis in sheep - The last 10 years and the future of research. Vet Microbiol. 2015; 181: 136-146.

Gezgen C, Seker E. Investigation of methicillin resistance and Panton-Valentine leukocidin in Staphylococci isolated from bovine mastitis. Acta Sci Vet. 2016; 44: 1373.

Huber H, Ziegler D, Pflüger V, Vogel G, Zweifel C, Stephan R. Prevalence and characteristics of methicillin-resistant coagulase-negative staphylococci from livestock, chicken carcasses, bulk tank milk, minced meat, and contact persons. BMC Vet Res. 2011; 7: 1-7.

Ikawaty R, Brouwer EC, van Duijkeren E, Mevius D, Verhoef J, Fluit AC. Virulence factors of genotyped bovine mastitis Staphylococcus aureus isolates in the Netherlands. Int J Dairy Sci. 2010; 5: 60-70.

Lina G, Piemont Y, Godail-Gamot F, Bes M, Peter M, Gauduchon V, Vandenesch F, Etienne J. Involvement of Panton-Valentine leukocidinproducing Staphylococcus aureus in primary skin infections and pneumonia. Clin Infect Dis. 1999; 295: 1128-1132.

Lo W, Wang C. Panton-Valentine leukocidin in the pathogenesis of community-associated methicillin-resistant Staphylococcus aureus infection. Pediatr Neonatol. 2011; 52: 59-65.

Martins KB, Faccioli-Martins PY, Riboli DFM, Pereira VC, Fernandes S, Oliveira AA, Dantas A, Zafalon LF, Cunha MLR. Clonal profile, virulence and resistance of Staphylococcus aureus isolated from sheep milk. Braz J Microbiol. 2015; 46: 535-543.

Moon JS, Lee AR, Kang HM, Lee ES, Kim MN, Paik YH, Park YH, Joo YS, Koo HC. Phenotypic and genetic antibiogram of methicillin-resistant Staphylococci isolated from bovine mastitis in Korea. J Dairy Sci. 2007; 90: 1176-1185.

Ozenc E, Seker E, Baki Acar D, Birdane MK, Darbaz I, Dogan N. The importance of Staphylococci and threshold value of somatic cell count for diagnosis of sub-clinical mastitis in Pirlak sheep at mid lactation. Reprod Domest Anim. 2011; 46: 970-974.

Pantosti A. Methicillin-resistant Staphylococcus aureus associated with animals and its relevance to human health. Front Microbiol. 2012; 3: 1-12.

Pinho MG, Filipe SR, de Lencastre H, Tomasz A. Complementation of the essential peptidoglycan transpeptidase function of penicillin-binding protein 2 (PBP2) by the drug resistance protein PBP2A in Staphylococcus aureus. J Bacteriol. 2001; 183: 6525-6531.

Queiroga MC. Prevalence and aetiology of sheep mastitis in Alentejo region of Portugal. Small Rumin Res. 2017; 153: 123-130.

Rainard P, Riollet C. Innate immunity of the bovine mammary gland. Vet Res. 2006; 37: 369-400.

Sharma-Kuinkel BK, Ahn SH, Rude TH, Zhang Y, Tong SYC, Ruffin F, Genter FC, Braughton KR, DeLeo FR, Barriere SL, Fowler VG. Presence of genes encoding panton valentine leukocidin is not the primary determinant of outcome in patients with hospitalacquired pneumonia due to Staphylococcus aureus. J Clin Microbiol. 2012; 50: 848-856.

Strommenger B, Kettlitz C, Werner G, Witte W. Multiplex PCR assay for simultaneous detection of nine clinically relevant antibiotic resistance genes in S. aureus. J Clin Microbiol. 2003; 41: 4089-4094.

Türkyılmaz S, Tekbiyık S, Oryasin E, Bozdogan B. Molecular epidemiology and antimicrobial resistance mechanisms of methicillin resistant Staphylococcus aureus isolated from bovine milk. Zoonoses Public Health. 2010; 57: 197-203.

Ünal N, Çinar OD. Detection of stapylococcal enterotoxin, methicillin-resistant and Panton-Valentine leukocidin genes in coagulase-negative staphylococci isolated from cows and ewes with subclinical mastitis. Trop Anim Health Prod. 2012; 44: 369-375.

Ünal N, Askar Ş, Macun HC, Sakarya F, Altun B, Yıldırım M. Panton-Valentine leukocidin and some exotoxins of Staphylococcus aureus and antimicrobial susceptibility profiles of staphylococci isolated from milks of small ruminants. Trop Anim Health Prod. 2012; 44: 573-579.

Vyletělová M, Hanuš O, Karpíšková R, Št’ástková Z. Occurrence and antimicrobial sensitivity in Staphylococci isolated from goat, sheep and cow's milk. Acta Univ Agric Silvic Mendel Brun. 2011; 59: 209-214.

Yilmaz O, Cengiz F, Ertugrul M, Wilson RT. The domestic livestock resources of Turkey: sheep breeds and crossbreeds and their conservation status. Anim Genet Resour. 2013; 52: 147-163.

Yoong P, Torres VJ. The effects of Staphylococcus aureus leukotoxins on the host: cell lysis and beyond. Curr Opin Microbiol. 2013; 16: 63-69. 